\title{
Rancang Bangun Sistem Informasi Penyebaran Penyakit Berbasis GUI Matlab (Studi kasus : Penyakit DBD)
}

\author{
Didi Supriyadi \\ Program Studi Informatika \\ Jl. DI Panjaitan No. 128 Purwokerto 53147 \\ didisupriyadi@st3telkom.ac.id
}

\begin{abstract}
Abstrak - Penyebaran penyakit bersifat laten dan merupakan permasalahan yang harus diantisipasi pencegahannya sedini mungkin. Salah satu jenis penyakit yang endemis di Indonesia adalah penyakit demam berdarah. Tujuan dari penelitian ini adalah untuk rancang bangun sistem informasi untuk penyebaran penyakit berbasis GUI Matlab. Untuk studi kasusnya adalah penyakit demam berdarah. Metode yang digunakan dalam penelitian ini menggunakan metode ANN Backpropagation untuk mengetahui tingkat penyebaran dengan menggunakan variabel yang mempengaruhi penyebaran penyakit demam berdarah yang digunakan dalam penelitian ini meliputi suhu rata - rata, curah hujan, jumlah hujan (dalam hari), kepadatan penduduk, ketinggian wilayah dan \% ABJ. Metode pengembangan sistem yang digunakan pada penelitian ini menggunakan metode skuensial linier. Dalam penelitian ini juga akan dipredikasi tingkat endemisitas dari penyebaran penyakit demam berdarah yang meliputi bebas, potensial, sporadis, dan endemis berdasarkan ada tidaknya kasus demam berdarah dua tahun yang lalu. Dari hasil pengamatan diperoleh hasil bahwa sistem dapat melakukan prediksi dengan baik. Dari hasil pengamatan diperoleh hasil tingkat validasi sistem sebesar $94,12 \%$.
\end{abstract}

Kata kunci : Sistem informasi; metode skuensial linier; demam berdarah; ANN Backpropagation; GUI; Matlab

\section{PENDAHULUAN}

Berbagai macam penyakit menular maupun tidak menular berkembang di Indonesia. Salah satu penyebab perkembangan penyakit tersebut dikarenakan tingkat mobilitas manusia yang terus meningkat dari hari ke hari karena perkembangan teknologi transportasi. Salah satu jenis penyakit yang berkembang di Indonesia adalah penyakit demam berdarah. Pada stratifikasi penyakit demam berdarah yang dilakukan oleh badan kesehatan dunia (WHO), pada tahun 2001 Indonesia masuk dalam kategori "A". Hal ini menandakan bahwa angka perawatan pada rumah sakit maupun kematian yang dikarenakan penyakit demam berdarah di negara Indonesia masih tinggi [2]

Penelitian ini bertujuan membuat sistem informasi untuk memprediksi penyebaran penyakit dalam kasus ini adalah penyakit demam berdarah dengan tingkat endemisitasnya berdasarkan kejadian / kasus pada dua tahun sebelumnya dengan GUI Matlab. Parameter yang di-input-kan pada sistem ini meliputi suhu rata rata, curah hujan, jumlah hujan (dalam hari), kepadatan penduduk, ketinggian wilayah serta pesren angka bebas jentik (ABJ).

\section{KERANGKA TEORI}

\section{A. Demam Berdarah}

Demam berdarah merupakan penyakit menular dan berbahaya. Hal ini dikarenakan waktu penyebarannya yang terjadi dalam waktu singkat dan sering menimbulkan kematian dan tak jarang menimbulkan wabah yang disebabkan oleh virus dengue. Virus ini dapat ditularkan melalui gigitan nyamuk Aedes aegypti yang populasinya hampir terdapat di seluruh indonesia terutama wilayah dengan ketinggian di bawah 1000 meter di atas permukaan air laut [8]. Perubahan keadaan kondisi tubuh bagi penderita penyakit demam berdarah terjadi sangat mendadak yang ditandai dengan demam tinggi, pusing, headache, nyeri tulang dan persendian, wajah pucat, serta pada kulit terdapat tanda merah yang diakibatkan oleh gigitan nyamuk [1].

Jumlah kejadian penyakit demam berdarah di Indonesia pada tahun 2002 sebanyak 40.377 dengan perbandingan incidence rate (IR) sebesar 19,24/100.000 penduduk. Dan pada tahun 2007 jumlah kejadian dan angka kematian terus meningkat yaitu berada pada angka 124.811 dengan IR sebesar $57,52 / 100.000$ penduduk dengan angka kematian mencapai angka 1.277 [3].

Menurut Ditjen PPM dan PL Departemen Kesehatan RI pada tahun 2003, klasifikasi daerah endemis DBD adalah seperti berikut ini:

a. Daerah Endemis, yaitu daerah yang dalam kurun waktu 3 tahun terakhir selalu ada kasus DBD.

b. Daerah Sporadis, yaitu daerah yang dalam kurun waktu 3 tahun terakhir ada kasus DBD.

c. Daerah Potensial, yaitu daerah yang dalam kurun waktu 3 tahun terakhir tidak ada kasus DBD akan tetapi berpenduduk padat, dan ditemukan jentik > $5 \%$.

d. Daerah bebas, yaitu daerah yang tidak pernah ada kasus. 


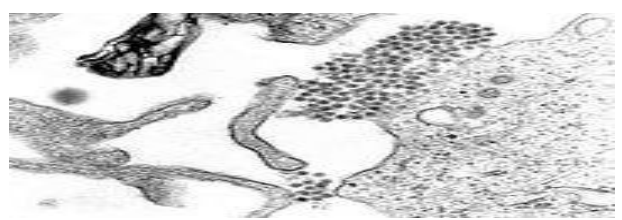

Gambar 1. Virus dengue Penyebab Penyakit Demam Berdarah

Sumber : http://wikipedia.org

\section{B. ANN Backpropagation}

ANN atau Artificial Neural Network merupakan model komputerisasi dari otak manusia yang merupakan sistem pengolahan informasi yang mempunyai karakteristik serupa dengan jaringan syaraf manusia. Komponen dasar pada sel syaraf biologis yang dijadikan model pada ANN adalah dendrit, soma, dan akson. ANN Backpropagation merupakan ANN dengan metode terawasi atau terbimbing. Artinya dalam proses pembelajaran sistem harus diberi contoh - contoh untuk dilatihkan sampai kriteria konvergensi tercapai [5]. Fase pelatihan ANN Backpropagation sebagai berikut :

\section{a. Feed forward / umpan maju \\ b. Backpropagation / propagasi balik \\ c. Perubahan bobot \\ C. Pengembangan Sistem}

Pengembangan sistem (systems development) merupakan set aktivitas, metode, standar proses ataupun langkah untuk pengembangan sistem atau penyusunan sistem baru untuk menggantikan sistem lama baik secara keseluruahn atau sebagaian sistem. Beberapa alasan yang sering muncul perlunya perbaikan sistem antara lain (1) adanya permasalahan yang timbul pada sistem lama, (2) untuk meraih kesempatan baru, dan (3) adanya instruksi dari pimpinan maupun dari luar organisasi. Tahapan utama siklus pengembangan sistem meliputi systems planning, systems analysis, systems design, systems selection, systems implementation, dan systems maintenance.

Rekayasa perangkat lunak merupakan stau cara atau aplikasi dari suatu pendekatan yang sistematik, teratur, terencana, dan dapat diukur terhadap proses pengembangannya, kinerja, dan perawatan perangkat lunak [7]. Salah satu model proses rekayasa perangkat lunak adalah model skuensial linier. Model ini dikenal sebagai kehidupan klasik ataupun model air terjun (waterfall model). Model ini mengusulkan pendekatan perangkat lunak yang sistemik dan skuensial yang diawali dari tingkat dan kemajuan sistem melalui beberapa tahap meliputi analisis, desain, pengkodean, pengujian, dan pemeliharaan.

Model skuensial linier terdiri atas beberapa tahap[7], yaitu :

a. Rekayasa dan pemodelan sistem/informasi

Software merupakan bagian dari sebuah sistem. Sehingga pekerjaan ini akan dimulai dengan menentukan syarat untuk tiap bagian dari sistem serta mengalokasikan beberapa sub-set dari persyaratan software tersebut. b. Analisis kebutuhan software

Hal ini bertujuan untuk memahami sifat dari suatu program yang akan dibuat. Seorang software developer maupun analis sistem harus mampu memahami domain informasi untuk software, serta fungsi yang dibutuhkan, kinerja, maupun antarmukanya.

c. Desain

Merupakan proses yang memiliki fokus pada atribut - atribut seperti : struktur data, arsitektur software, antarmuka, dan algoritma. Proses desain merupakan proses menterjemahkan kebutuhan ke dalam representasi dari software yang dapat dinilai akan kualitasnya sebelum pengkodean dimulai.

d. Code generation

Merupakan proses ataupun tugas penterjmahan desain ke dalam bentuk bahasa yang dapat dimengerti oleh mesin.

e. Testing

Proses pengujian menitikberatkan pada logika dari software dalam melakukan tes untuk mengungkap error dan memastikan bahwa masukan yang didefinisikan akan menghasilkan hasil yang aktual sesuai dengan yang dibutuhkan.

f. Pemeliharaan

Merupakan proses atau langkah dalam upaya penerapan kembali setiap tahapan sebelumnya yang mungkin dikarenakan kesalahan tertentu.

\section{GUI Matlab}

Matlab merupakan bahasa level tinggi untuk komputasi teknik. Matlab mengintegrasikan antara komputasi, visualisasi, dan pemrograman dalam penggunaannya untuk memudahkan penyelesaian masalah yang solusinya dinyatakan dalam notasi matematika yang mudah dimengerti[6]. Matlab merupakan sistem interaktif yang elemen dasarnya berupa array yang tidak memerlukan dimensi. Sehingga memungkinkan kita untuk menyelesaikan masalah teknis komputasi, terutama yang terkait dengan matriks dan vektor. Matlab merupakan singkatan dari Matriks Laboratory. Awalnay Matlab dikembangkan untuk memberikan kemudahan akses ke software matriks yang dikembangkan oleh LINPACK dan EISPACK project [6].

Sistem pada Matlab terdiri dari Desktop tools and Development Environment, Matlab Mathematical Function Library, Matlab Language, Graphics, dan Matlab External Interfaces. Pada sistem Graphics, Matlab memiliki fasilitas yang luas untuk menampilkan vektor dan matriks sebagai grafik, dan pencetakan grafik tersebut. Ini termasuk fungsi tingkat tinggi untuk visualisasi data dua dimensi dan tiga dimensi, grafis pengolahan gambar, animasi, dan presentasi. Matlab juga mencakup fungsi tingkat rendah yang memungkinkan Anda untuk sepenuhnya menyesuaikan tampilan grafis serta untuk membangun antarmuka pengguna grafis yang lengkap pada Aplikasi Matlab kita[6].

GUIDE, merupakan lingkungan pengembangan antarmuka pengguna grafis Matlab yang menyediakan satu set alat untuk membuat grafis user interfaces atau yang sering dikenal sebagai GUI. Guide ini 
merupakan tool yang berfungsi untuk menyederhanakan proses layout dan pemrograman GUI.

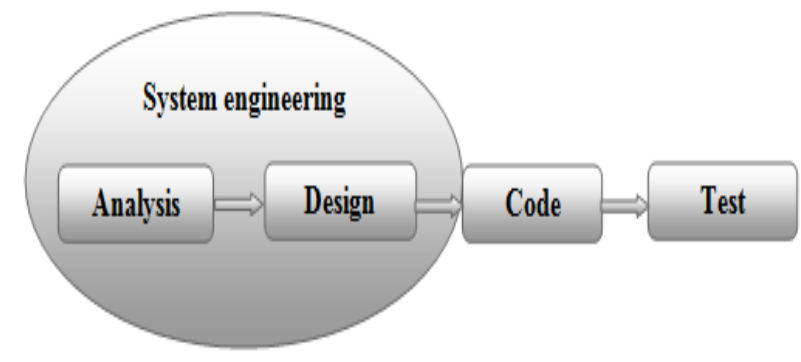

Gambar 2. Model Skuensial Linier (Pressman, 2001)

\section{METODOLOGI}

\section{A. Desain Penelitian}

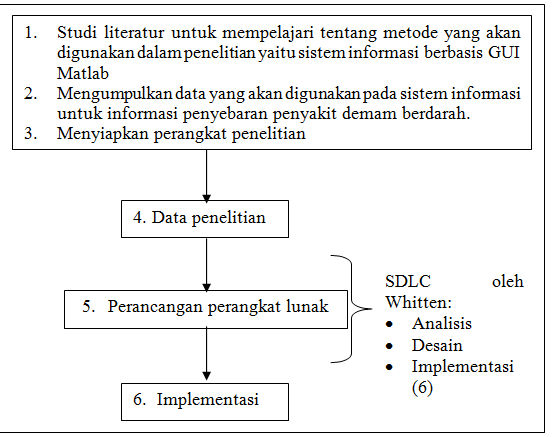

Gambar 3 Desain Penelitian

Pada penelitian ini tahapan - tahapan desain penelitian yang dilakukan antara lain (Gambar 3):

1. Studi literatur untuk mempelajari tentang metode yang akan digunakan dalam penelitian yaituSistem Informasi berbasis GUI Matlab serta studi tentang kasus yang akan diteliti yaitu kasus prediksi penyebaran penyakit demam berdarah.

2. Mengumpulkan data yang akan digunakan pada sistem informasi untuk prediksi penyebaran penyakit demam berdarah berbasis GUI Matlab

3. Menyiapkan perangkat penelitian.

4. Data penelitian

5. Perancangan perangkat lunak untuk prediksi penyebaran penyakit demam berdarah

6. Implementasi

\section{B. Metode Penelitian}

Metodologi yang diterapkan dalam penelitian ini meliputi metode pengumpulan data dan metode pengembangan sistem.

\section{Metode pengumpulan data}

Metode pengumpulan data meliputi metode studi literatur dan wawancara. Langkah - langkah pengumpulan data yang dilakukan pada penelitian ini adalah mengelompokkan data masukan dan data keluaran sebagai data pengujian.

Data - data terkait faktor lingkungan yang mempengaruhi penyebaran penyakit demam berdarah diperoleh dari berbagai sumber dari pemerintah
Kabupaten Brebes, untuk data suhu rata - rata diperoleh dari Badan Meteorologi Klimatologi dan Geofisika (BMKG) Kabupaten Brebes yang masih menginduk dengan BMKG Kota Tegal, sedangkan data curah hujan, jumlah hari hujan, kepadatan penduduk dan ketinggian wilayah diperoleh dari Badan Pusat Statistik (BPS) Kabupaten Brebes dan untuk data persentase Angka Bebas Jentik (\% ABJ) dari Dinas Kesehatan Kabupaten Brebes. Selain enam parameter tersebut yang digunakan sebagai variabel input dari sistem yang akan dikembangkan, dalam penelitian ini juga mengambil data kasus DBD yang digunakan sebagai target ataupun output dari sistem yang diperoleh dari Dinas Kesehatan Kabupaten Brebes. Pasangan input dan target yang digunakan dalam penelitian ini diperlihatkan dalam Gambar 4

$\left.\begin{array}{|l|}\hline \text { Suhu Rata - Rata } \\ \hline \text { Curah Hujan } \\ \hline \text { Jumlah Hari Hujan } \\ \hline \text { Kepadatan Penduduk } \\ \hline \text { Ketinggain Permukaan Air Laut } \\ \hline \% \text { Angka Bebas Jentik } \\ \hline \text { Kondisi DBD / Bebas } \\ \hline\end{array}\right\} \quad$ Target

Gambar 4 Pasangan Input dan Target Sistem

Prediksi penyebaran penyakit DBD berbasis GUI Matlab ini menggunakan data historis. Data primer yang digunakan dalam penilitian ini adalah data yang diambil secara time series, sehingga ada 102 pasangan data yang telah diperoleh merupakan data nilai tahunan dari enam parameter tersebut yang meliputi 17 kecamatan yang ada di Kabupaten Brebes dari tahun $2005-2010$.

\section{Metode pengembangan sistem}

Pada pengolahan data keluaran dari sistem dikelompokkan kedalam dua kondisi keluaran yaitu, kondisi suatu wilayah terhadap kasus demam berdarah direpresentasikan dengan bilangan biner 0 dan 1 seperti yang ditunjukkan pada Tabel 1 beserta keterangannya untuk ada dan tidaknya kasus penyakit demam berdarah, kondisi yang kedua adalah tingkat endemisitasnya yang direpresentasikan dalam empat kategori keadaan yaitu keadaan : Bebas, Potensial, Sporadis, dan Endemis.

Tabel 1. Representasi Nilai keluaran Sistem

\begin{tabular}{|c|c|}
\hline Keluaran & Representasi \\
\hline 0 & Bebas \\
\hline 1 & Ada kasus DBD \\
\hline
\end{tabular}




\section{Desain Sistem berbasis GUI Matlab}

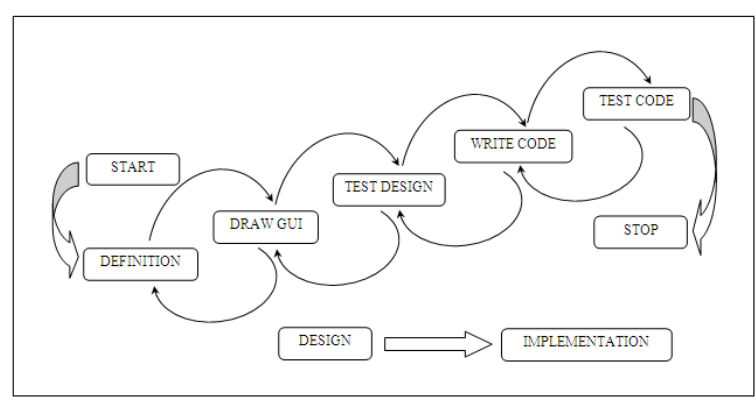

Gambar 5. Proses Perancangan GUI

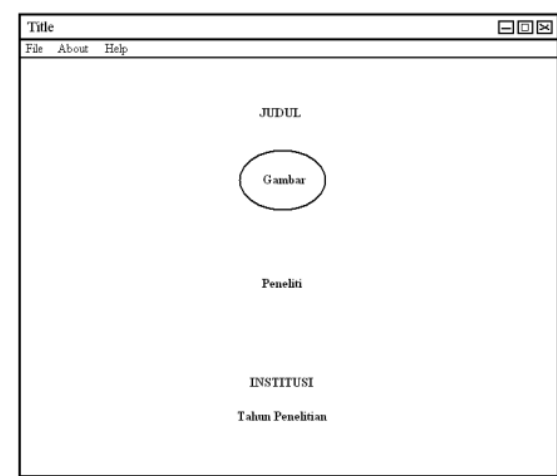

Gambar 6. Kerangka Tampilan Menu Utama

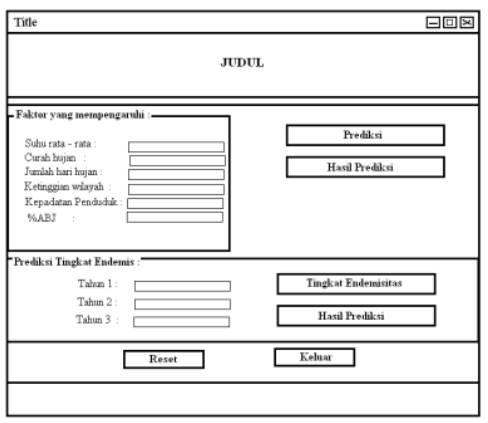

Gambar 7. Kerangka Tampilan Menu Informasi

Graphic User Interface (GUI) merupakan sarana tampilan dalam bentuk grafis sebagai pengganti perintah teks untuk pengguna berinteraksi [4]. Pada sistem yang dikembangkan dalam penelitian ini dikembangkan beberapa antarmuka meliputi tampilan utama dan tampilan informasi. Proses pembuatan GUI pada Matlab dapat dituangkan ke dalam beberapa tahap dari perancangan hingga tahap implementasi [5].

Desain dari tampilan utama berisi judul sistem, logo yang merepresentasikan sistem, nama peneliti, institusi dan tahun penelitian serta beberapa menu pilihan yang terdiri dari menu File, Help, dan About. Rancangan tampilan utama ditunjukkan pada Gambar 6. Pada menu File akan diarahkan ke menu informasi (Gambar 7), sedangkan menu About berisi tentang sistem yang dibuat.

\section{HASIL DAN PEMBAHASAN}

\section{A. Desain Antarmuka}

\section{1) Tampilan Utama}

Pada tampilan utama terdapat judul dari sistem yang dibuat dalam penelitian yaitu "Rancang Bangun Sistem Informasi Penyebaran Penyakit Berbasis GUI Matlab" yang ditunjukkan oleh Gambar 8.

\section{2) Tampilan Informasi}

Sebelum melakukan proses prediksi penyebaran penyakit dalam kasus ini adalah penyebaran penyakit demam berdarah, kita harus memasukkan nilai - nilai pada variabel masukan berupa nilai - nilai dari faktor lingkungan yang mempengaruhi penyebaran penyakit demam berdarah meliputi : suhu rata - rata, jumlah hari hujan, curah hujan, kepadatan penduduk, ketinggian wilayah serta persen ABJ. Kemudian tekan button "INFORMASI" untuk memulai proses prediksi. Tampilan informasi ditunjukkan oleh Gambar 9.

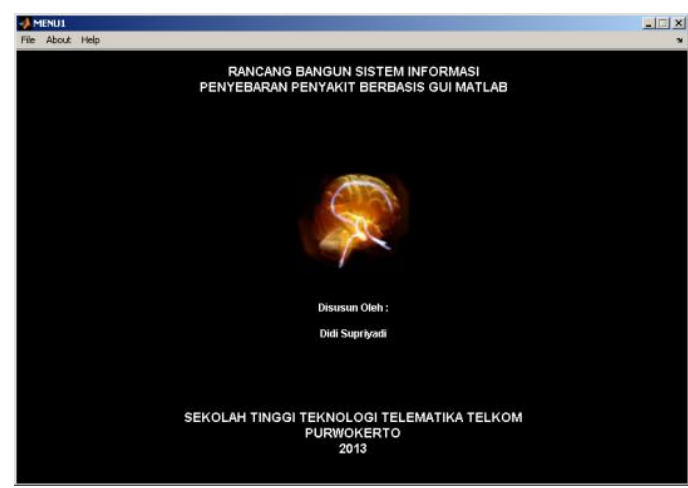

Gambar 8. Tampilan Utama

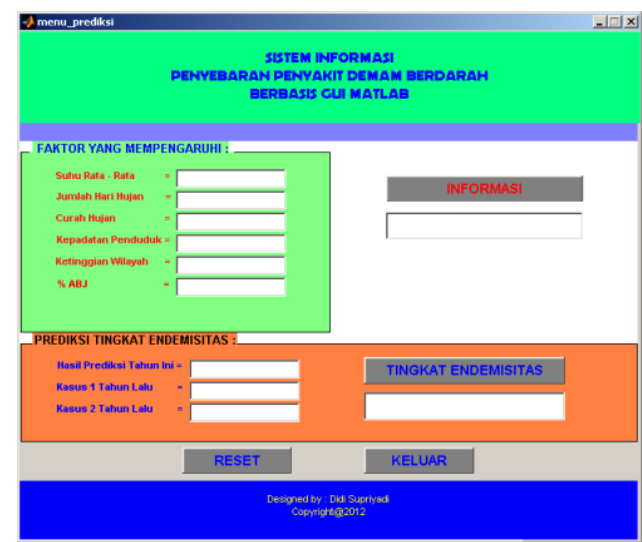

Gambar 9. Tampilan Informasi

\section{B. Pembahasan}

Berdasarkan Tabel 2 terlihat hasil pengujian sistem menunjukkan tingkat ketepatan yang baik antara output sistem dengan target yang diharapkan. Sehingga dapat dihitung tingkat validasi dari sistem yang dikembangkan dalam penelitian ini sebagai berikut :

$$
\begin{gathered}
\text { Validasi }=\left[\frac{\text { Jumlah_data_uji_sesuai_t } \arg \text { et }}{\text { Jumlah_data_uji }}\right] \times 100 \% \\
\text { validasi }(\%)=\left|\frac{16}{17}\right| \times 100 \% \\
\text { Validasi }=94,12 \%
\end{gathered}
$$


Tabel 2. Data untuk Pengujian Sistem

\begin{tabular}{|c|c|c|c|c|c|c|c|c|c|c|c|}
\hline \multirow[t]{2}{*}{ No } & \multicolumn{6}{|c|}{ Variabel Lingkungan } & \multicolumn{3}{|c|}{$\begin{array}{c}\text { Kasus } 3 \text { Tahun Terakhir } \\
\text { (Tahun ke-III merupakan } \\
\text { Target Kasus untuk tiap } \\
\text { tahun) }\end{array}$} & \multirow{2}{*}{$\begin{array}{c}\text { Ket. } \\
\text { Kasus } \\
\text { tahun ke- } \\
\text { III }\end{array}$} & \multirow[t]{2}{*}{ Endemisitas } \\
\hline & Suhu & $\begin{array}{c}\text { Hari } \\
\text { Hujan }\end{array}$ & $\begin{array}{l}\text { Curah } \\
\text { Hujan }\end{array}$ & $\begin{array}{l}\text { Kepadatan } \\
\text { Penduduk }\end{array}$ & $\begin{array}{c}\text { Ketinggian } \\
\text { Wilayah }\end{array}$ & $\% \mathrm{ABJ}$ & $\begin{array}{c}\text { Tahun } \\
\text { I }\end{array}$ & $\begin{array}{c}\text { Tahun } \\
\text { II }\end{array}$ & $\begin{array}{c}\text { Tahun } \\
\text { III }\end{array}$ & & \\
\hline & & & & & & & 2008 & 2009 & 2010 & & \\
\hline 86 & 24.8 & 182 & 3327 & 375 & 500 & 53 & 0 & 0 & $\mathrm{~V}$ & $\mathrm{DBD}$ & Potensial \\
\hline 87 & 27 & 245 & 4032 & 427 & 161 & 100 & 0 & 0 & 0 & Bebas & Bebas \\
\hline 88 & 27 & 274 & 4035 & 1303 & 162 & 100 & $\mathrm{~V}$ & $\mathrm{~V}$ & 0 & Bebas & Sporadis \\
\hline 89 & 26 & 164 & 4226 & 919 & 342 & 100 & 0 & 0 & 0 & Bebas & Bebas \\
\hline 90 & 23 & 182 & 3327 & 919 & 875 & 100 & 0 & 0 & 0 & Bebas & Bebas \\
\hline 91 & 27 & 174 & 4378 & 800 & 175 & 100 & 0 & 0 & 0 & Bebas & Bebas \\
\hline 92 & 27.6 & 167 & 3393 & 832 & 23 & 41 & $\mathrm{~V}$ & $\mathrm{~V}$ & $\mathrm{~V}$ & $\mathrm{DBD}$ & Endemis \\
\hline 93 & 27.6 & 145 & 3039 & 895 & 17 & 36 & V & $\mathrm{V}$ & V & DBD & Endemis \\
\hline 94 & 27.6 & 210 & 3511 & 848 & 22 & 53 & $\mathrm{~V}$ & $\mathrm{~V}$ & $\mathrm{~V}$ & DBD & Endemis \\
\hline 95 & 27.7 & 150 & 2941 & 1349 & 5 & 29 & $\mathrm{~V}$ & $\mathrm{~V}$ & $\mathrm{~V}$ & DBD & Endemis \\
\hline 96 & 27.8 & 122 & 1910 & 1354 & 3 & 30 & $\mathrm{~V}$ & $\mathrm{~V}$ & $\mathrm{~V}$ & DBD & Endemis \\
\hline 97 & 27.6 & 182 & 3327 & 2300 & 11 & 33 & $\mathrm{~V}$ & $\mathrm{~V}$ & $\mathrm{~V}$ & DBD & Endemis \\
\hline 98 & 27.8 & 110 & 3003 & 1576 & 3 & 61 & $\mathrm{~V}$ & $\mathrm{~V}$ & $\mathrm{~V}$ & DBD & Endemis \\
\hline 99 & 27.9 & 153 & 2869 & 1889 & 1 & 56 & $\mathrm{~V}$ & $\mathrm{~V}$ & $\mathrm{~V}$ & DBD & Endemis \\
\hline 100 & 27.7 & 228 & 3833 & 1402 & 5 & 56 & $\mathrm{~V}$ & $\mathrm{~V}$ & $\mathrm{~V}$ & DBD & Endemis \\
\hline 101 & 27.7 & 189 & 3048 & 2376 & 5 & 45 & $\mathrm{~V}$ & $\mathrm{~V}$ & $\mathrm{~V}$ & DBD & Endemis \\
\hline 102 & 27.8 & 181 & 2360 & 1945 & 3 & 30 & $\mathrm{~V}$ & $\mathrm{~V}$ & $\mathrm{~V}$ & $\mathrm{DBD}$ & Endemis \\
\hline
\end{tabular}

Tabel 3. Hasil Pengujian Sistem

\begin{tabular}{|c|c|c|c|c|c|}
\hline Data & Target & $\begin{array}{c}\text { Output } \\
\text { Sistem }\end{array}$ & Error & Keterangan Sistem & Endemisitas \\
\hline 1 & 1 & $\mathbf{0}$ & $\mathbf{1}$ & Tidak ada Kasus & Bebas \\
\hline 2 & 0 & 0 & 0 & Tidak ada Kasus & Bebas \\
\hline 3 & 0 & 0 & 0 & Tidak ada Kasus & Sporadis \\
\hline 4 & 0 & 0 & 0 & Tidak ada Kasus & Bebas \\
\hline 5 & 0 & 0 & 0 & Tidak Ada Kasus & Bebas \\
\hline 6 & 0 & 0 & 0 & Tidak Ada Kasus & Bebas \\
\hline 7 & 1 & 1 & 0 & Terjadi Kasus DBD & Endemis \\
\hline 8 & 1 & 1 & 0 & Terjadi Kasus DBD & Endemis \\
\hline 9 & 1 & 1 & 0 & Terjadi Kasus DBD & Endemis \\
\hline 10 & 1 & 1 & 0 & Terjadi Kasus DBD & Endemis \\
\hline 11 & 1 & 1 & 0 & Terjadi Kasus DBD & Endemis \\
\hline 12 & 1 & 1 & 0 & Terjadi Kasus DBD & Endemis \\
\hline 13 & 1 & 1 & 0 & Terjadi Kasus DBD & Endemis \\
\hline 14 & 1 & 1 & 0 & Terjadi Kasus DBD & Endemis \\
\hline 15 & 1 & 1 & 0 & Terjadi Kasus DBD & Endemis \\
\hline 17 & 1 & 1 & 0 & Terjadi Kasus DBD & Endemis \\
\hline
\end{tabular}




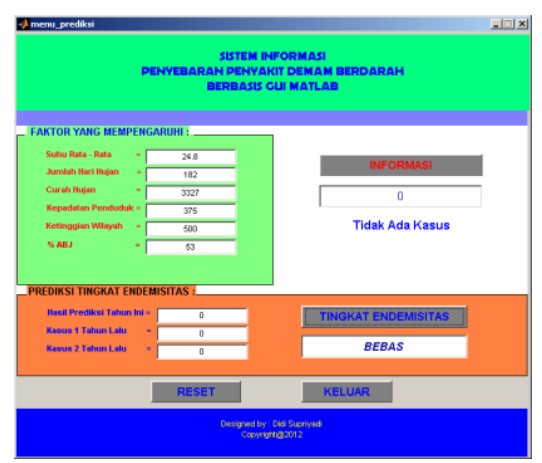

Gambar 10. Hasil Pengujian Data 1

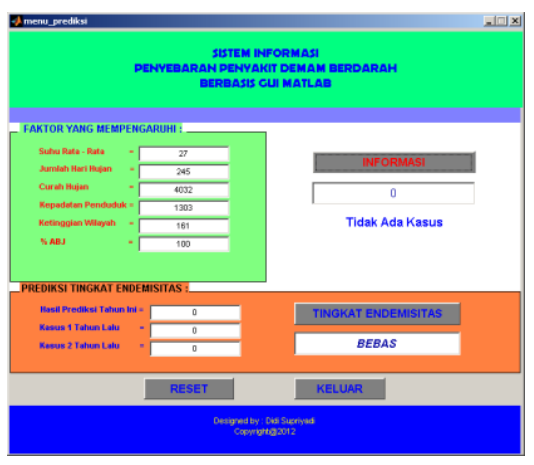

Gambar 11. Hasil Pengujian Data 2

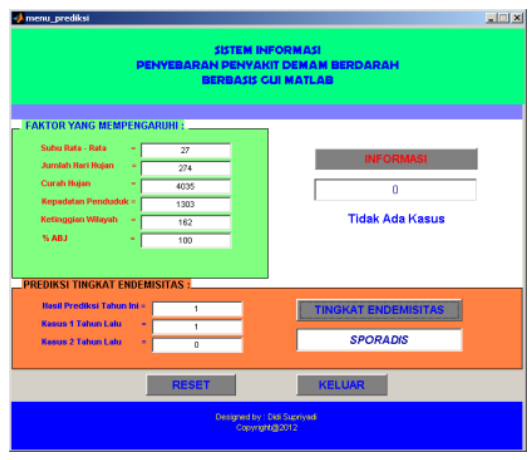

Gambar 12. Hasil Pengujian Data 3

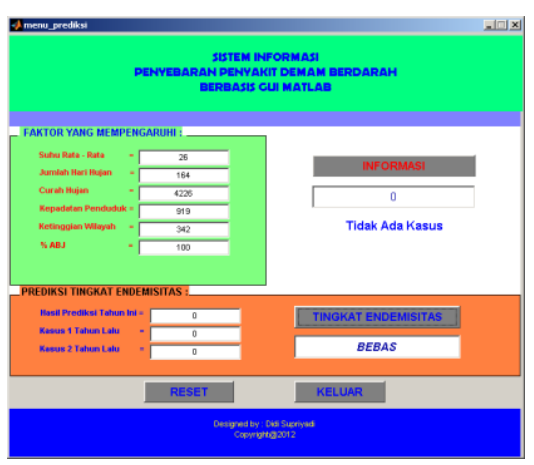

Gambar 13. Hasil Pengujian Data 4

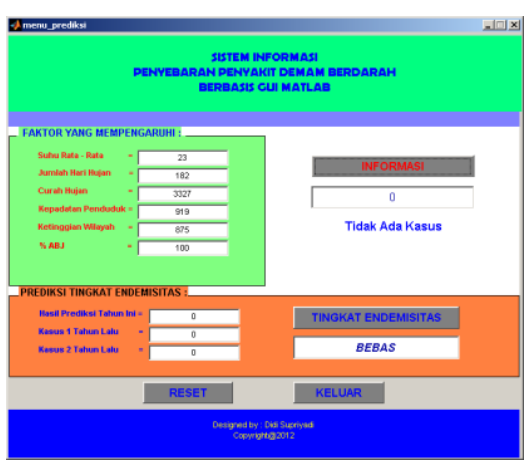

Gambar 14. Hasil Pengujian Data 5

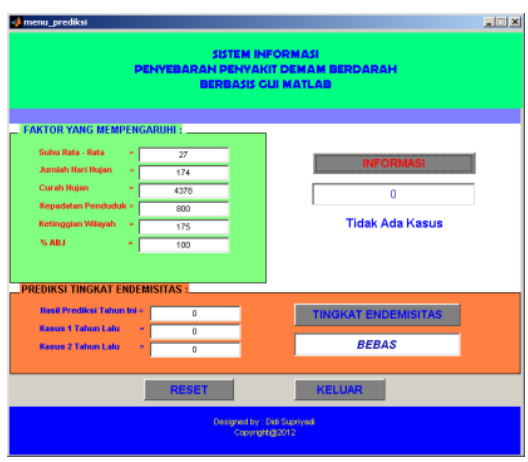

Gambar 15. Hasil Pengujian Data 6

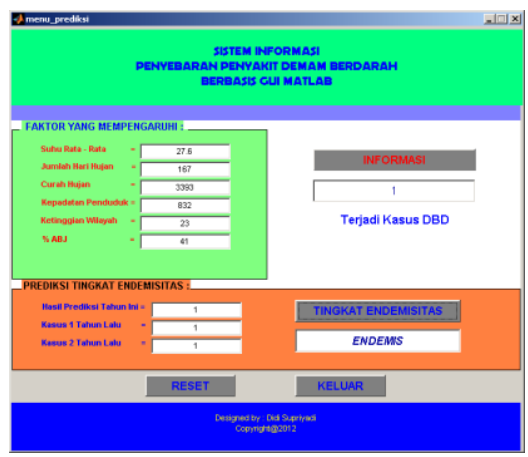

Gambar 16. Hasil Pengujian Data 7

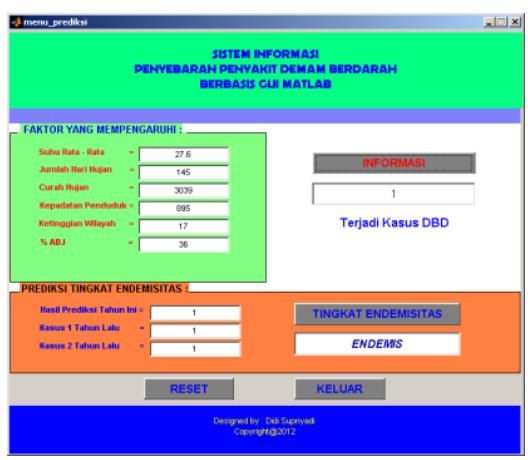

Gambar 17. Hasil Pengujian Data 8 


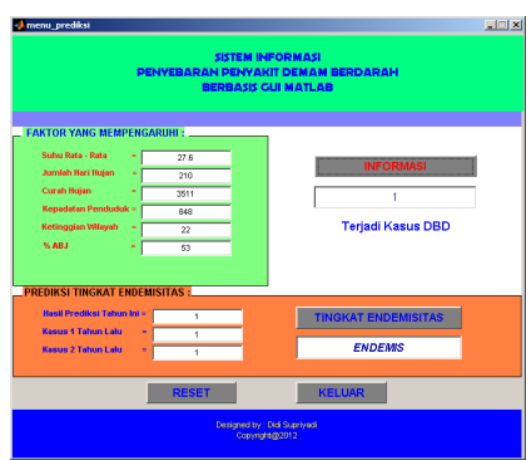

Gambar 18. Hasil Pengujian Data 9

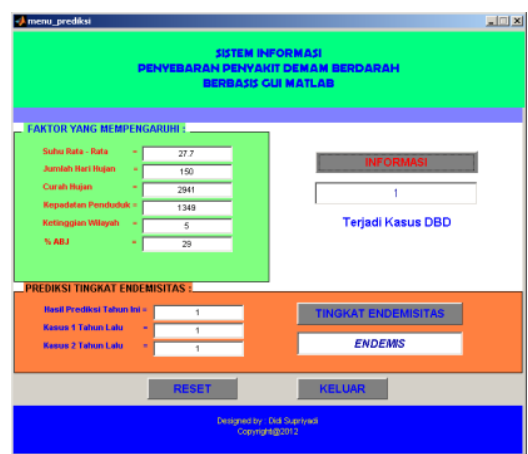

Gambar 19. Hasil Pengujian Data 10

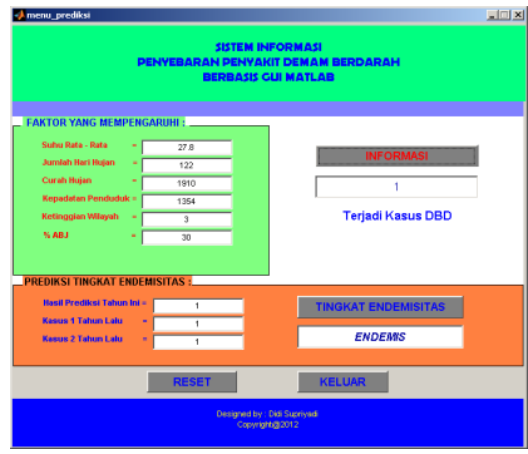

Gambar 20. Hasil Pengujian Data 11

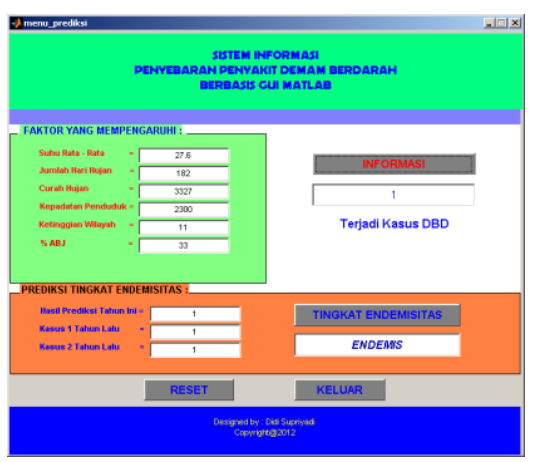

Gambar 21. Hasil Pengujian Data 12

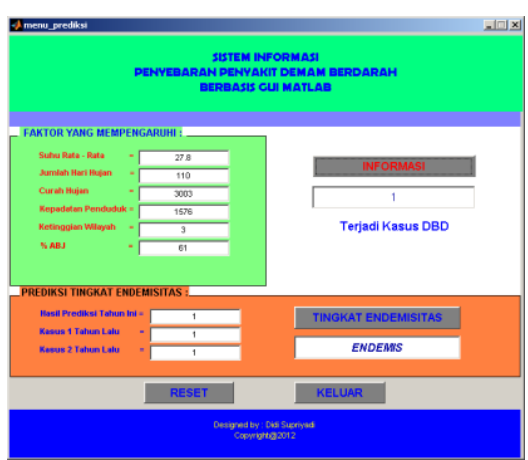

Gambar 22. Hasil Pengujian Data 13

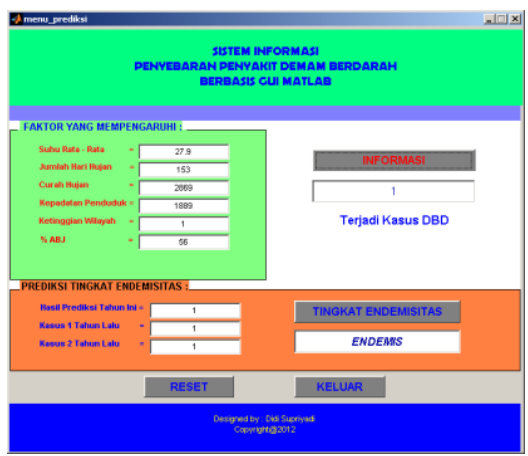

Gambar 23. Hasil Pengujian Data 14

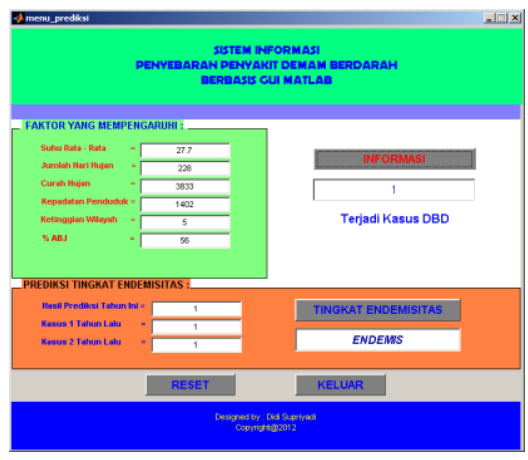

Gambar 24. Hasil Pengujian Data 15

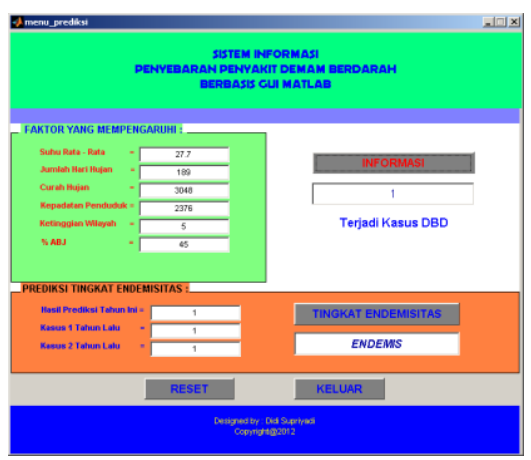

Gambar 25. Hasil Pengujian Data 16 


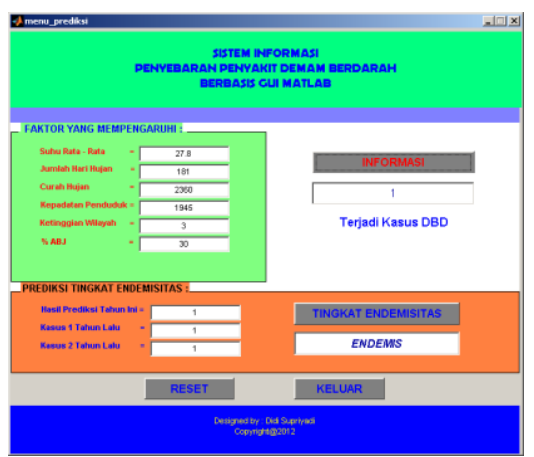

Gambar 26. Hasil Pengujian Data 17

\section{KESIMPULAN}

Berdasarkan hasil pengamatan yang dilakukan pada penelitian ini (Gambar 10 - 26), diketahui bahwa dari 17 data pengujian ada satu data yang error yaitu data nomer 1 sedangkan 16 data lainnya keluaran dari sistem sesuat dengan target. Hal ini menunjukkan tingkat akurasi sistem sangat baik dengan tingkat akurasi di atas $90 \%$.

\section{ACKNOWLEDGMENT}

Peneliti menyampaikan ucapan terima kasih kepada seluruh pihak yang terkait dalam penelitian ini dan institusi Sekolah Tinggi Teknologi Telematika
Telkom Purwokerto yang telah memberikan wadah kepada peneliti untuk melakukan penelitian ini.

\section{REFERENSI}

[1] Agarkar, A.M., Ghatol, A.A., 2010, FFANN Based Cost Effective Major Infant Disease Management. International Journal of Computer Applications (0975 8887)Vol. 7.

[2] Chen, K., Pohan, H.T., Sinto, R., 2009. Diagnosis dan Terapi Cairan pada Demam Berdarah Dengue. Medicinus. Vol. 22 No.1.

[3] Dirjen PP \& PL., 2007. Pemberantasan Sarang Nyamuk Demam Berdarah Dengue (PSN - DBD) oleh Juru Pemantau Jentik (Jumantik). Depkes RI, Jakarta.

[4] Gunaidi, 2006. The Shortcut of MATLAB Programming. Informatika, Bandung.

[5] Hermawan, A., 2006. Jaringan Saraf Tiruan Teori dan Aplikasi. Andi, Yogyakarta.

[6] MathWorks, Inc. 2007. Getting Started with MATLAB 7. MathWorks Inc.

[7] Pressman, R.S., 2001. Software Engineering A Practitioner's Approach 5th edition McGraw-Hill. New York.

[8] Sukamto, 2007. Studi Karakteristik Wilayah dengan Kejadian DBD di Kecamatan Cilacap Selatan Kabupaten Cilacap. Magister Kesehatan Lingkungan, Universitas Diponegoro, Semarang. 